University at Buffalo School of Law

Digital Commons @ University at Buffalo School of Law

$1-1-2013$

\title{
Multipolar Governance Across Environmental Treaty Regimes: The Ramsar Convention in Its Middle Age
}

Kim Diana Connolly

University at Buffalo School of Law

Follow this and additional works at: https://digitalcommons.law.buffalo.edu/journal_articles

Part of the Environmental Law Commons, and the International Law Commons

\section{Recommended Citation}

Kim D. Connolly, Multipolar Governance Across Environmental Treaty Regimes: The Ramsar Convention in Its Middle Age, 107 Proceedings of the ASIL Ann. Meeting 440 (2013).

Available at: https://digitalcommons.law.buffalo.edu/journal_articles/636

\section{C) ${ }_{\text {COPYRIGHT }}^{\text {N }}$}

This Article is brought to you for free and open access by the Faculty Scholarship at Digital Commons @ University at Buffalo School of Law. It has been accepted for inclusion in Journal Articles by an authorized administrator of Digital Commons @ University at Buffalo School of Law. For more information, please contact lawscholar@buffalo.edu. 
Protocol, test the boundaries of what it means to gain "access"' to genetic resources, and challenge, as a practical matter, the capacity to enforce restrictions on transfer.

Proposals to expand the CBD's coverage to include genetic resources found outside national jurisdiction or collected prior to its entry into force would compound rather than remedy the anticommons problem. Further complication or expansion of regulation will not encourage the partnerships needed to share knowledge or develop benefits. A better remedy would be to foster flexible collaborations based on trust, an emerging ethic of fair dealing, and sharing of benefits, broadly defined, in the relevant disciplines.

\title{
Multipolar Governance Across Environmental Treaty Regimes: The Ramsar Convention in Its Middle Age
}

\author{
By Kim Diana Connolly*
}

\section{INTRODUCTION}

Adopted in 1971, the Ramsar Convention has entered "middle age." ${ }^{1}$ In 2013, the Ramsar Convention (formally known as the Convention on Wetlands of International Importance especially as Waterfowl Habitat) ${ }^{2}$ continues to bring countries together to support wetlands. ${ }^{3}$ The Ramsar Convention is the only international environmental treaty that focuses on a specific ecosystem: wetlands. The Convention defines wetlands very broadly, to include " areas of marsh, fen, peatland or water, whether natural or artificial, permanent or temporary, with water that is static or flowing, fresh, brackish or salt, including areas of marine water the depth of which at low tide does not exceed six metres., ${ }^{4}$ My remarks will discuss the Ramsar Convention generally, and reflect on its role in the world of multipolar governance.

\section{Historical Context and Current LaW}

The Ramsar Convention emerged in 1971 after more than eight years of work by concerned nations and nongovernmental organizations. ${ }^{5}$ First signed by representatives of 18 countries

\footnotetext{
* Professor and Vice Dean for Legal Skills, Director of the Environmental Law Program, and Director of Clinical Legal Education, SUNY Buffalo Law School. The author has served on the U.S. National Ramsar Committee since 2006, and attended the Ramsar Conferences of the Parties in 2008 and 2012. She can be reached at kimconno@buffalo.edu.

${ }^{1}$ There is no agreed-on definition of "middle age," and in fact the U.S. Census Bureau has moved away from using that term. See U.S. Census Bureau, Age and Sex Composition: 2010, 2010 Census Brief, http://www.census.gov/ $\mathrm{prod} / \mathrm{cen} 2010 / \mathrm{briefs} / \mathrm{c} 2010 \mathrm{br}-03$.pdf. But many would agree that those over the age of 40 are in the middle-age range. See, e.g., middleage.org, Definition -When or What Is Middle Age?, http://www.middleage.org/definition.shtml.

${ }^{2}$ Convention on Wetlands of International Importance Especially as Waterfowl Habitat (Feb. 2, 1971), T.I.A.S. No. 1084, 996 U.N.T.S. 245 (amended 1982 \& 1987) [hereinafter Ramsar Convention]. A current copy of the Ramsar Convention text can be found at http://www.ramsar.org/cda/en/ramsar-documents-texts/main/ramsar/1-3138_4000_0_.

${ }^{3}$ See generally www.ramsar.org.

${ }^{4}$ Ramsar Convention art. 1. This is much more broad than the definitions of wetlands used under U.S. regulations and guidance. See generally U.S. Environmental Protection Agency, http://water.epa.gov/lawsregs/guidance/wetlands/definitions.cfm.

${ }^{5}$ G.V.T. Matthews, The Ramsar Convention on Wetlands: Its History and Development (1993) (recounting that "[i]t took just over eight years of conferences, technical meetings and behind the scenes discussions to develop a convention text"), available at http://www.ramsar.org/cda/en/ramsar-pubs-books-ramsar-conventionon-21313/main/ramsar/1-30-101\%5E21313_4000_0_.
} 
in Ramsar, Iran $^{6}$ in February of $1971,{ }^{7}$ it entered into force in $1975 .^{8}$ The Convention represented a dramatic shift from historic perspectives on wetlands as "disastrous realms, sources of disease, [and] obstacles to any form of positive development." "9 The Convention ${ }^{10}$ has been amended twice, ${ }^{11}$ and signatories regularly come together in Conferences of the Parties to negotiate and agree to other important guidance documents. ${ }^{12}$ Under the current strategic plan, the Convention has five goals:

(1) To work towards achieving the wise use of all wetlands ...;

(2) To develop and maintain an international network of wetlands that are important for the conservation of global biological diversity ... ;

(3) To enhance the conservation and wise use of wetlands using effective international cooperation ... ;

(4) To progress towards fulfillment of the Convention's mission by ensuring that it has the required mechanisms, resources, and capacity to do so . . . ; and

(5) To progress towards universal membership of the Convention. ${ }^{13}$

Unaffiliated with the United Nations system of Multilateral Environmental Agreements, ${ }^{14}$ the Convention Secretariat is headquartered in Switzerland ${ }^{15}$ and receives intercessional guidance from a Standing Committee. ${ }^{16}$ The Secretariat and signatories also receive expert scientific and policy guidance from its Scientific and Technical Review Panel (STRP). ${ }^{17}$ Member countries are encouraged to create National Ramsar Committees, ${ }^{18}$ which tend to

\footnotetext{
${ }^{6}$ The Convention's short form is not an acronym, but rather signifies name of the town (Ramsar, Iran) where it was originally signed.

${ }^{7}$ The original 1971 version of the Convention can be found at http://www.ramsar.org/cda/en/ramsar-documentscops-1971-final-act-of-the/main/ramsar/1-31-58-136\%5E20803_4000_0_.

${ }^{8}$ By its terms, the Ramsar Convention was to enter into force four months after seven parties had ratified it. Ramsar Convention, supra note 2, art. 10. For a current introduction to the history of the Convention, see A Brief History of the Ramsar Convention, http://www.ramsar.org/cda/en/ramsar-about-history/main/ramsar/1-3662_4000_0_. The United States became a party in 1987 during the Reagan administration. See Contracting Parties in Order of their Accession, http://www.ramsar.org/cda/en/ramsar-about-parties-parties-in-order/main/ramsar/1-36123\%5E20715_4000_0_.

${ }^{9}$ Matthews, supra note 5.

${ }^{10}$ For a superb overview of the Convention, including its history and modern implementation, see THE RAMSAR Convention Manual: A Guide to the Convention on Wetlands (Ramsar, Iran, 1971) (6th ed. 2013), available at http://www.ramsar.org/pdf/lib/manual6-2013-e.pdf [hereinafter RAMSAR MANUAL].

${ }^{11}$ The actual language of the incorporated amendments can be found at the official documents site: http:// www.ramsar.org/cda/en/ramsar-documents-texts/main/ramsar/1-31-38_4000_0_.

${ }^{12}$ Guidelines adopted by the Conference of the Contracting Parties to the Ramsar Convention on Wetlands, http://www.ramsar.org/key_guidelines_index.htm. This website provides links to various guidance documents officially adopted during meetings of the Conference of the Contracting Parties.

${ }^{13}$ The Ramsar Strategic Plan 2009-2015 as adopted by Resolution X.1 (2008) and adjusted for the 2013-2015 triennium by Resolution XI.3 (2012), http://www.ramsar.org/pdf/strat-plan-2009-e-adj.pdf.

${ }^{14}$ See generally Basic Information on Secretariats of?Multilateral Environmental Agreements, Mission, Structure, Financing and Governance, http://www.un.org/ga/president/60/summitfollowup/060612d.pdf.

${ }^{15}$ See The Ramsar Secretariat, http://www.ramsar.org/cda/en/ramsar-about-bodies-secr/main/ramsar/1-36-7177_4000_0_.

${ }^{16}$ See The Standing Committee, http://www.ramsar.org/cda/en/ramsar-about-bodies-standing/main/ramsar/1-3671-73_4000_0_.

${ }^{17}$ See The Scientific and Technical Review Panel (STRP): Ramsar's Scientific Subsidiary Body, http://www.ramsar.org/cda/en/ramsar-about-bodies-strp/main/ramsar/1-36-71-74_4000_0_.

${ }^{18}$ See Ramsar Resolution 5.6: The Wise Use of Wetlands, Annex A, http://www.ramsar.org/cda/en/ramsardocuments-resol-resolution-ix-1-annex-a/main/ramsar/1-31-107\%5E23536_4000_0__(suggesting that establishment of national wetland committees can assist with meeting "wise use" obligations).
} 
vary from country to country in terms of composition and role in meeting the convention's obligations. $^{19}$

Under the Convention, each party must designate at least one site of international importance. Designation requires meeting official criteria, and completing a Ramsar Information Sheet (RIS) with data on and support for the proposed site. ${ }^{20}$ Once approved, sites join the List of Wetlands of International Importance. ${ }^{21}$ Upon its listing, a party is obliged "to promote the conservation of the site." 22 However, the Convention provides that listing a site "does not prejudice [a party's] exclusive sovereign rights.,"23

Likewise, the Convention requires each party to apply "wise use" to all wetlands in a party's territory. ${ }^{24}$ This mandate has been viewed as predecessor of so-called "sustainability" concepts. ${ }^{25}$ International cooperation is another Ramsar Convention cornerstone, and has led to various relationships with related instruments and organizations with similar goals. ${ }^{26}$

\section{Ramsar in a Multipolar Context}

The materials introducing the American Society of International Law's 2013 Annual Meeting, "International Law in a Multipolar World," posed the following queries: "How will the international legal order evolve to reflect this new multipolar world? Will the international legal order undergo significant change as the global balance of power and influence shifts?", 27 These are interesting queries in the context of the middle-aged framework convention that is Ramsar. ${ }^{28}$

Ramsar Convention decisionmaking has always involved nonstate actors with expertise in wetlands. There is little "enforcement" of the Convention, and despite focus on wise use obligations, few parties have fought to overcome political will against what many would deem unwise use. Although research suggests a Ramsar designation has enhanced wetland conservation for sites (by increasing various factors, including local awareness, information

\footnotetext{
${ }^{19}$ See National Ramsar Committees, http://www.ramsar.org/cda/en/ramsar-activities-nationalramsarcommittees/ main/ramsar/1-63-516_4000_0_.

${ }^{20}$ See Information Sheet on Ramsar Wetlands (RIS), http://www.ramsar.org/cda/en/ramsar-documents-info-information-sheet-on/main/ramsar/1-31-59\%5E21253_4000_0_. A new process for completing and updating future RISs was approved in 2012. Resolution XI.8: Streamlining Procedures for Describing Ramsar Sites at the Time of Designation and Subsequent Updates, http://www.ramsar.org/pdf/cop11/res/cop11-res08-e.pdf.

${ }^{21}$ The current list of sites is maintained by the NGO partner Wetlands International, http://ramsar.wetlands.org/.

${ }^{22}$ Ramsar Convention, supra note 2, art. 3.1.

${ }^{23} I d$. art. 2.3 .

${ }^{24}$ See Ramsar Manual, supra note 10, at 47.

${ }^{25}$ Id.; see generally What Is the "Wise Use", of Wetlands?, http://www.ramsar.org/cda/en/ramsar-about-faqswhat-is-wise-use/main/ramsar/1-36-37\%5E7724_4000_0_.

${ }^{26}$ Related instruments and organizations include the United Nations Environment Programme (UNEP); The Convention on Biological Diversity (CBD); The Convention on Conservation of Migratory Species of Wild Animals (CMS); The UNESCO World Heritage Convention; the United Nations Convention to Combat Desertification (UNCCD); the United Nations Framework Convention on Climate Change (UNFCCC); UNEP's Convention for the Protection and Development of the Marine Environment of the Wider Caribbean Region and other regional conventions; UNESCO's Man and the Biosphere Programme; the Global Terrestrial Observing System (GTOS); and others. See Memoranda of Understanding and Cooperation with Other Conventions and International Organizations, http://www.ramsar.org/cda/en/ramsar-documents-mous/main/ramsar/1-31-115_4000_0_.

${ }^{27}$ ASIL, http://www.asil.org/am13/.

${ }^{28}$ Framework conventions, which leave treaty details for later negotiations, are deemed to be most common in environmental law. Nele Matz-Lück, Framework Conventions as Regulatory Tools, 1 Goettingen J. InT'L L. 439 (2009).
} 
exchange, funding, science, tourism, etc.), ${ }^{29}$ it remains an open question how effective Ramsar itself has been at actually ensuring wetlands preservation globally. Heated negotiations over resolutions addressing controversial issues such as climate change $\mathrm{e}^{30}$ at the last Ramsar Conference of the Parties ${ }^{31}$ lend support to the argument that Ramsar is important to states and nonstate actors alike, but globally shifting balances of power as multipolarity increases may affect the Convention's ability to meet its mission and truly protect.

\section{Multipolar and Multilevel Governance in the Arctic and the Antarctic}

\section{By Timo Koivurova*}

The aim of my remarks is three-fold. First, to examine whether nongovernmental organizations have been able to influence the way environmental protection is done in the two polar regions. Second, to examine whether the changing geopolitical power balance has had an effect on how Arctic and Antarctic regimes function. And third, to query whether environmental governance in these regimes is strengthened through NGO access and/or by including the rising powers of Asia.

\section{Who Is Competent to Conduct Environmental Protection in the Polar Regions?}

From the viewpoint of environmental governance, it is of great importance whether a specific environment forms part of the sovereign territory of a state or not. If a territory is under the sovereignty of a state, it is this state that has competence in enacting, implementing, and applying rules with respect to environmental protection.

Here the Arctic and the Antarctic differ greatly. In the Antarctic, the sovereignty question has been "frozen" and thus there are no territorial sovereigns on the continent. Seven states claimed parts of the Antarctic as their sovereign area before the conclusion of the 1959 Antarctic Treaty. Yet with this legally binding convention these claimant states agreed not to consolidate these claims into full sovereignty for the duration of the treaty. This state of affairs is likely to continue far into the future. The situation in the Arctic contrasts sharply with this legal status. All of the land area-continents as well as islands-is firmly under the sovereignty of the Arctic states. A significant portion of Arctic waters (which contains the overarching majority of Arctic offshore resources including fossil fuel deposits and potential fisheries) now falls under their maritime jurisdiction.

Since there are no territorial sovereigns in Antarctica, international institutions have historically both enacted and overseen environmental protection efforts in the region. This has also led to the international collective approach to governing the environment of the Antarctic. Antarctic Treaty Consultative Meetings (ATCM) have adopted treaties protecting seals,

\footnotetext{
${ }^{29}$ Royal C. Gardner \& Kim Diana Connolly, The Ramsar Convention on Wetlands: Assessment of International Designations Within the United States, 37 EnvTL. L. ReP. 10089 (2007); Royal C. Gardner, Kim Diana Connolly \& Abou Bamba, African Wetlands of International Importance: Assessment of Benefits Associated with Designations Under the Ramsar Convention, 23 Geo. InT'L ENVTL. L. Rev. 257 (2008).

${ }^{30}$ Resolution XI.14: Climate Change and Wetlands: Implications for the Ramsar Convention on Wetlands, http:// www.ramsar.org/pdf/cop11/res/cop11-res14-e.pdf.

${ }^{31}$ The 11th Meeting of the Conference of the Contracting Parties, http://www.ramsar.org/cda/en/ramsar-documents-cops-cop11-cop11-proceedings/main/ramsar/1-31-58-500\%5E25863_4000_0_.

* Research Professor and Director of the Northern Institute for Environmental and Minority Law, Arctic Centre, University of Lapland.
} 